\begin{tabular}{|l|l|l|l|l|}
\hline \multirow{2}{*}{ a } & \multicolumn{1}{|c|}{ CUtara } & cuan_1124 & Dispatch: December 10, 2011 & CE: N/A \\
\cline { 2 - 5 } & Journal & MSP No. & No. of pages: 25 & PE: Sarah \\
\hline
\end{tabular}

\title{
BLACKOUTS AND PROGRESS: Privatization, Infrastructure, and a Developmentalist State in Jimma, Ethiopia
}

\section{DANIEL MAINS \\ Colby College}

"What's new in Addis Ababa?" I asked the cab driver who was delivering me from Bole International Airport to my hotel in the Piazza neighborhood at the center of Ethiopia's capital. He responded without hesitation: "There is a problem with electricity. We get electricity in turns." As we moved away from the expensive hotels and restaurants near the airport, I noticed that all the buildings were cloaked in darkness. The only light came from other cars and the occasional lantern in a shop window. My driver explained that electricity was being transmitted in shifts, with different neighborhoods receiving power on alternate days, 24 hours on and 24 hours off. Although power outages are not infrequent in Ethiopian cities, I had never encountered such regular and extended outages before my 2009 trip.

When I traveled to Jimma, the city in southwest Ethiopia where I have intermittently conducted research since 2002, talk of blackouts continued. Friends who have lived in Jimma for more than 60 years told me that they have never experienced anything like this. These scheduled power outages are especially odd given that the Gibe River, which flows near Jimma, was recently dammed and at the time was the largest source of source of hydropower in the country. The Ethiopian government, in conjunction with a private Italian company, Salini, is currently constructing two even larger hydroelectric projects. ${ }^{1}$ The cost of these projects is well over $\$ 1$ billion, with the money coming largely from loans from the Italian government, the European Investment Bank, and the African Development Bank. ${ }^{2}$ 
cuan_1124 can2008.cls December 10, 2011 19:19

CULTURAL ANTHROPOLOGY 27:1

Many critics say that by constructing hydropower dams in Ethiopia, Salini seeks to maximize profits through its relationship with a weak state and international lenders (CEE Bankwatch Network 2008:1). In a 2006 report the Ethiopian government anticipated that by 2009 not only would the power system meet the demands of the domestic population but also Ethiopia would be able to export power to Djibouti, Sudan, and Kenya (Hathaway 2008). Yet on this visit, as I moved through the city at night, I was confronted with either total darkness or the loud hum of gas-powered generators.

Initially, I felt that I was observing what James Ferguson (2006) and others have described as the thinning of the state in neoliberal Africa. Writing about urban Nigeria, Brian Larkin explains, "In the disaggregation from networked electricity to autonomous generators lies the shift in Nigerian society from the developmental state to new forms of individual, competitive liberalism" (2008:244). Like Nigeria, in a context of liberalizing economic reforms, the Ethiopian state can no longer provide its citizens with electricity, a basic public service that urban residents have come to take for granted. ${ }^{3}$ Instead infrastructural development and the provision of many services are contracted to international companies, which generate significant profits. At the same time the quality of life in Ethiopia declines further, as individuals are left to fend for themselves. Businesses and a few wealthy families own generators, others rely on candles and lanterns, and many cannot afford any source of light at all.

After a few days in Jimma I realized that power outages are not the only change to have occurred since my last visit in 2008. The air was full of the dust of construction. Multistory buildings were springing up all over town, roads were being covered with fresh layers of asphalt, and trenches were being excavated for new water lines. Amid power outages and a global economic crisis, Jimma was booming with urban renewal projects. A Korean company was improving a road connecting Jimma with peripheral areas to the south, and a Chinese company was expanding Jimma's airport to give it international status.

In many ways the hydroelectric and road construction projects are similar. Both are financed with loans from international organizations, and private contractors based outside of Ethiopia are carrying out the work. Just as the new dams coincided with blackouts, rather than increased access to electricity, the unfinished roads disrupted traffic and in some cases displaced families. Despite these similarities, in day-to-day discussions the residents of Jimma spoke about the projects quite differently. Although the hydroelectric projects were viewed with suspicion and 4 doubt, there was a great deal of faith in the potential for roads to bring economic 
development. When I asked people about the value of new roads their responses were often simple: "Progress." Roads bring progress, and the Ethiopian government is bringing roads. In this case there was no perceived rolling back of the state, in which the state fails to provide expected public services. Rather the state had the power to create jobs, transform the city, and improve life. Like Charles Piot (2010), I am interested in perceptions of an increasingly absent African state. In the Ethiopian case, however, partly because of its partnerships with international private companies, the state is perceived as reemerging and generating linear development.

In this article, I examine this apparent contradiction in perceptions of development projects. Following Donald Moore's (1999) call to investigate development in terms of situated and heterogeneous cultural practices, I argue that contrasting conceptions of dams and roads emerge from values concerning relations of power and exchange. In doing so I engage with Ferguson's (2006) discussion of the neoliberal state in Africa. I do not dispute Ferguson's argument that African states are increasingly more involved in the work of legitimizing resource extraction by international companies than in governing, but I do argue that faith in progressive narratives and a developmentalist state continues to be quite powerful. The Ethiopian case demonstrates how "expectations of modernity" (Ferguson 1999) through state-led development may emerge at surprising junctures. I examine the relationship among citizenship, the state, and social welfare that anthropologists have explored in Latin America and postsocialist states (Caldeira 2001; Holston 2009; Verdery 1996). The perception that road construction brings progress demonstrates that urban Ethiopians actively engage with the privatization of infrastructural development to discursively construct relations with the state, and these representations have important implications for class relations and the legitimacy of public resource distribution. ${ }^{4}$

This article also seeks to contribute to anthropological discussions of neoliberalism. Aihwa Ong concisely defines the primary elements of neoliberal political philosophy as both a claim that the market is better than the state at distributing public resources and the emergence of highly competitive individualism that often expresses itself in terms of consumption (2006:11). When critical analyses of neoliberalism are applied in much of the world, it is often the case that when one of these elements is identified, then other aspects of a vague but singular "neoliberalism" are also assumed to exist. Often the presence of neoliberal doctrine is assumed to overlap with David Harvey's (2005) notion of neoliberalism as a class project, in which wealth is increasingly consolidated in the hands of a few. Such 
cuan_1124 can2008.cls December 10, 2011 19:19

CULTURAL ANTHROPOLOGY 27:1

analyses gloss over the various ways in which neoliberal policies interact with local dynamics, as well as the critiques of anthropologists (Ferguson 2007; Kingfisher and Maskovsky 2008; Kipnis 2008; Mains 2007; Richland 2009). Partially in reaction to critiques of conceptions of a singular neoliberalism, anthropologists have increasingly advocated examinations of locally specific neoliberalisms and how people rework neoliberal discourses and processes in new and surprising ways (Ellison 2009; Kanna 2010; Rudnyckyj 2009; Schwegler 2008). Although there is certainly value in this move, the notion of multiple neoliberalisms is still rooted in the overly broad category of "neoliberal." In these analyses it is often unclear which aspects of neoliberalism are being retained and which discarded in the formation of localized neoliberalisms.

I adopt an approach similar to Stephen Collier's (2009) call for a topology of power that examines the correlation between particular techniques and relations of power. Collier explains that a topological analysis "brings to light a heterogeneous space, constituted through multiple determinations, and not reducible to a given form of knowledge/power. It is better suited to analyzing the dynamic process through which existing elements, such as techniques, schemas of analysis, and material forms, are taken up and redeployed, and through which new combinations of elements are shaped" (2009:100). In other words, rather than basing my analysis in the ambiguous concept of neoliberalism(s), my concern is with the relationships between specific practices. In this article, I hope to contribute to a growing body of anthropological analyses that examine infrastructure, privatization, and changing relations of power (Ghosh 2006; Larkin 2008; Shever 2008; Von Schnitzler 2008). In doing so I seek not only to destabilize neoliberalism as a coherent project but also to question its continuing value as an analytical category. ${ }^{5}$

I begin with a brief description of normative values concerning relations of power and exchange in urban Ethiopia, particularly as they relate to engagement with the state and the role of large-scale development projects in legitimizing state power. I argue that beginning in the 1990s, the introduction of policies intended to downsize the Ethiopian public sector greatly restricted the state's ability to provide public services. This discussion offers context for an analysis of conversations I had in 2009 with Jimma residents concerning dams, roads, and other development projects. The contrasting perspectives presented in these discussions indicate that although the provision of basic services for its population is increasingly contracted out to private companies, the Ethiopian state is perceived as expanding in new and 6 surprising ways. In the conclusion I return to my argument concerning the utility 
of neoliberalism as an analytical category. Rather than interpreting the Ethiopian case as a particular permutation of neoliberalism, I argue that other more specific ways of speaking about policy and human experience are necessary.

\section{THE STATE, DEVELOPMENT, AND RELATIONS OF POWER IN ETHIOPIA}

Power relationships in much of Ethiopia have long been legitimized by the perception that those in power provide protection and support for their subordinates (Hoben 1970, 1973; Poluha 2004). In his work on land tenure among rural Amhara, Allan Hoben $(1970,1973)$ explained that relations of power were almost entirely vertical and were generally structured along the lines of a patron-client relationship. Put simply, lords provided a degree of protection for peasants and sometimes assisted them in litigating for land; in turn peasants paid taxes in the form of grain and labor, and gave their lords social and political support. In this sense, the continued power of the lord was based partially on his ability to provide tangible benefits for his subjects. With urbanization, government employment took the place of nobility as a source of power and a means of distributing favors to others. As Hoben (1970:222) notes in describing Addis Ababa under the reign of Haile Sellasie, the authority of the lord had been replaced by the government administrator, and education had taken the place of military activity as a means for accessing social mobility.

Although Jimma's history is distinct from other cities in Ethiopia (Gemeda 1987; Hassen 1990; Lewis 2001), many of the dynamics I describe concerning the relationship between infrastructural development and relations with the state may be applied broadly to urban Ethiopia. As Jimma began to develop a permanent residential urban population during the Haile Sellasie regime, after the brief Italian occupation ended in 1941, dynamics similar to other Ethiopian cities began to take hold. Land was expropriated from the local Oromo Muslim population, and an urban middle class of government administrators emerged that consisted primarily of Amhara and Oromo Orthodox Christians who had moved to Jimma from the Shoa region. Among men, access to prestige and income were both closely bound together with government employment, and the developing occupational and classbased hierarchy mapped onto religious and ethnic identity. In this article, I analyze perceptions of infrastructural projects primarily in terms of class and normative values concerning exchange and power. Ethnicity, gender, nationality, and religion are also highly relevant for how individuals position themselves in relation to the state in Ethiopia (James et al. 2002). However, for the sake of analytical focus, I put 
cuan_1124 can2008.cls December 10, $2011 \quad 19: 19$

CULTURAL ANTHROPOLOGY 27:1

these issues aside to better explore the interconnections between infrastructural development and relations of power with the state.

Under the Derg regime that replaced Haile Sellasie in $1974,{ }^{6}$ the language of development (limat) was increasingly employed as the state carried out a number of large projects aimed at improving quality of life (Donham 1999). ${ }^{7}$ This period represents a movement toward legitimizing power through state-led development, rather than individual patron-client relationships. Perhaps the most dramatic intervention attempted under the Derg was the major resettlement campaign that took place during the famine of the 1980s (Pankhurst 1992; Pankhurst and Piguet 2009; Scott 1998). Under the leadership of Mengistu Haile Mariam, the Derg forced rural residents to settle in villages to improve access to government services, organize farmers into cooperatives, and promote mechanization (Scott 1998:248). Between 1984 and 1986 over 600,000 people were resettled (Pankhurst 1992:56). Alula Pankhurst has explained that in a context of famine and dependence on foreign aid, "resettlement was seen as a positive and purposive measure initiated by the Government under the leadership of the vanguard party" (1992:53). In other words, resettlement signified the power of the state to act on behalf of the people. The fact that such state-led resettlement ultimately resulted in dramatic failure at great human cost was one of many reasons for the mobilization of massive resistance to the Derg and its eventual fall in 1991. The resettlement campaigns of the 1980s are clear examples of how attempts to legitimize state power through development in Ethiopia have often devolved into repression. When people resisted resettlement and questioned its benefits, the state found it necessary to employ force.

Although the ideologies and structures of rule have clearly changed, based on research conducted among children in Addis Ababa, Eva Poluha (2004) has argued that the patron-client model represents a source of continuity in Ethiopian power relationships extending from the prerevolutionary period, through the Derg, and to the current Ethiopian People's Revolutionary Democratic Front (EPRDF) regime. Under the revolutionary Derg, the state increasingly sought to legitimize itself through large-scale development, but the patron-client model has persisted as an important dynamic for structuring relations of power. Like the power relationships described by Hoben, in contemporary urban Ethiopia subordinate individuals and groups accept and support the rule of others as long as they are provided with social, emotional, and economic safety (Poluha 2004:95). In interviews I conducted concerning unemployment, young men and women often expressed the idea that it is the government's responsibility to provide them with an education and work, and 8 they blamed the state for the problem of unemployment. Although young people 
had little faith that the government would solve their problems, on a personal level they sought to form relationships with government workers to receive increased access to opportunities for education, work, and housing. Even at the lowest levels, government workers were able to provide economic and social benefits to friends and family. These ranged from expediting bureaucratic paperwork to providing access to valuable opportunities with development NGOs. In return, government workers received social support that was important for accumulating local power and prestige. ${ }^{8}$

The combination of an increasingly abstract state-citizen contract in which the power of the state is legitimized through development and the continued importance of personal patron-client relations provides the basic context for understanding urban Ethiopian reactions to the privatization of infrastructural development. Personal relationships continue to be very important for power dynamics in urban Ethiopia. As I will detail below, however, these relationships need not be formed with specific patrons. Instead, individuals seek to embed themselves within social networks by becoming part of the state.

\section{ECONOMIC RESTRUCTURING AND SHIFTING RELATIONS OF POWER}

Although Ethiopia's history differs from that of former European colonies in Africa, the rise of the developmentalist state in Ethiopia during the 1970s mirrors trends found throughout the global south (McMichael 1996; Rist 2002). Primarily through international borrowing, postcolonial governments expanded dramatically by investing in education, health care, infrastructure, and other public services. As in other countries, in Ethiopia discourse highlighting poverty and need was used to legitimize the expansion of the state. For example, in justifying the massive resettlement plan, Mengistu Haile Mariam invoked the rhetoric of need and the potential for growth, pronouncing, "while we have we lack, and when we could be lending we are beggars" (Pankurst 1992:52).

The coming to power of the EPRDF in 1991 marked a significant economic and political transition, but state-led development has persisted as a means of legitimizing political rule. The EPRDF initially espoused a Marxist doctrine, but soon after taking power the government began to open national markets and privatize public holdings (Ellison 2009). This shift was at least partially motivated by a need to access funds through the International Monetary Fund (IMF). As in other African countries, these policies have created patterns of uneven international 
investment and have exacerbated preexisting debts. Fluctuations in the international price of coffee, Ethiopia's primary export, and regional drought also contributed to a long period of economic contraction from which the country has only recently emerged.

There is certainly evidence that, similar to other African nations under the Structural Adjustment Policies of the IMF and World Bank, Ethiopian state programs have been rolled back. However, any simple claims that the state has disappeared from people's everyday lives may be quickly dismissed. In 2002, for example, the state engaged in a major resettlement campaign in response to famine. Over 600,000 people were relocated between 2003 and 2007 (Pankhurst and Piguet 2009:138). For better or worse, a state that physically moves so many people clearly cannot be said to have abandoned the business of governing. The mobilization of troops to fight a border war with Eritrea from 1998 to 2000 is further evidence of the ability of the Ethiopian state to take on major projects without the assistance of private contractors, despite economic restructuring.

Although there is some continuity in the role of the state in shaping people's everyday lives, important changes have emerged during the post-1991 period. The Derg regime was also limited in the services it could provide, but after 1991 IMF-mandated reforms required a significant downsizing of the public sector that has impacted citizen-state relations. The percentage of men in the labor force who were employed in the public sector fell from 65 percent in 1990 (the final year of the Derg) to about 30 percent in 1997 (Krishnan et al. 1998:10). Furthermore, under the current EPRDF regime many public services are now provided by private companies and are paid for by consumers. For example, as in much of the developing world, mobile phone ownership has exploded in urban Ethiopia and has become the primary means of communication. Another example is the opening of expensive and high-quality private schools. In Jimma a private elementary school opened with fewer than 50 students in 2002, and by 2009 it had more than 1,000 students in grades one through eight. The state continues to provide low-cost schools that are utilized by the majority of the population, but especially at the elementary level the gap in quality between public and private schools is so great that many young men claimed that one should not have children without the ability to pay for private education.

A growing cynicism toward the Ethiopian state was expressed in riots and outbursts of violence carried out predominantly by young men following the 2005 Ethiopian elections. Prior to the election there was an increasing sentiment among 10 young people that the Ethiopian state had failed to secure opportunities for work 
and education for their current generation. Feeling that the ruling party had unjustly stolen the elections, young people took to the streets to protest. These protests were violently put down by police, and tens of thousands of young men were detained for months in camps outside of Addis Ababa. ${ }^{9}$

Critiques of the state have not been confined to such protests. In 2008 a text message began circulating in late May, on the public holiday marking the overthrow of the Derg and the coming of the EPRDF. The message connected critiques of the state's failure to provide adequate service for mobile phones and control the rapidly rising price of staple foods. During my time in Jimma in 2008 it was nearly impossible to make a call using a mobile phone, and attempts were met with the automated responses listed on the right in the message quoted below. Texting generally did work, and the popular text message read as follows: ${ }^{10}$

When you make a call to:

Teff [the grain used to make injera, the staple food in urban Ethiopia] — Out of network

Kibe [clarified butter; used in many dishes] - Recharge your account

Shiro [chickpea paste; often eaten daily with injera] — Failed. Retry

Dabo [bread] — Line is busy

Meat-Switched off

Democracy_ Out of service area

Water-Press 5 days to refill your baldi [bucket]

Electricity - Out of the country. Please contact your generator.

Particularly given the cynicism and general resistance directed toward the state, reactions to recent development projects are surprising. Despite the apparent rolling back of the state in Africa, in the Ethiopian case the government works with nongovernmental actors to assert itself in people's day-to-day lives.

\section{SEEPAGE, SUSPICION, AND HYDROPOWER}

As I spent time in Jimma in 2009, I was struck by a strange combination of growth and economic decline. The value of the Ethiopian birr was falling rapidly in relation to international currencies, the cost of living was rising, and people seemed to be struggling more than before. Dramatic increases in the price of food were a constant topic of conversation. ${ }^{11}$ It had become impossible for many families to eat three meals a day. However, roads were being renewed, high-rises were going up, the government was creating jobs, and Ethiopia's GDP grew at a rate of more than eight percent between 2001 and 2010 (Economist 2011). The contradictory 
cuan_1124 can2008.cls December 10, 2011 19:19

CULTURAL ANTHROPOLOGY 27:1

narratives surrounding infrastructural development that I encountered emerge out of this context of simultaneous boom and bust.

In the heat and noise of the city, Ahmed's house is an oasis of cool and quiet. ${ }^{12}$ When I visit in the afternoon Ahmed and his friends are usually lounging on floor mats chewing khat (a leaf chewed as a mild stimulant) and talking. My closest friend at Ahmed's house is a teacher named Getachew. Getachew and I often talked about the Gibe River Dam that was recently completed near Jimma. When speaking, Getachew occasionally pauses to light a cigarette or push another wad of leaves into his mouth, but he never loses his focus. He speaks rapidly in a loud voice that is better suited for classes of 80 students than for Ahmed's small room. He can talk for a long time if I let him.

Getachew, a lifelong Jimma resident, explained that when he was born around 50 years ago there was no problem with electricity. Jimma was initially powered by a generator, and then electricity was generated by Finchaa Dam. Only since the Gibe River Dam became the primary source of power have the outages begun.

I told Getachew about a conversation I had with a friend who works for the state electric power office. My friend's explanations were similar to those that had appeared in state-run media and claimed that the power cuts are because of supply and demand. Demand has increased for two reasons: first, there is more industry in Ethiopia than in the past, and second, the government has committed to provide electricity to at least 50 percent of the rural population. In terms of supply, Ethiopia relies entirely on hydroelectric power, and other power sources are needed to meet the added demand created by bringing electricity to rural areas. When I mentioned the Gibe River Dam, he explained that the project is not finished. Furthermore, without more rain the dam cannot adequately supply power.

These sounded like reasonable explanations, and yet according to Getachew they are all in some way flawed. "There is a lot of new industry near Addis Ababa," Getachew explained, "but almost none in the rest of the country. These new factories are not enough to be the cause of the blackouts. Supplying the countryside with power is difficult, this is true, but why would the government do this without adequate resources? If this is really the problem, then the government could easily reverse its decision and cut off electricity to the countryside." "What about the shortage of water?" I asked. "It's true, there is a shortage of water in Gil Gel Gibe," Getachew argued. "But it cannot be because of lack of rain. It has been raining. There is no denying that it has been raining. We have seen the rain.”

The state explanation and Getachew's critique demonstrate their contrasting positions. The official explanation implies both that the state gives too much and 
that any problems are beyond its control. It is because of state-led development, in the form of growing industry and extending the power grid to rural areas, that blackouts occurred. However, Getachew's response places blame entirely on the state. The weather cannot be responsible because the presence of rain is plain for all to see. Getachew's denial of industrial growth is also a denial of the state's claims to have generated economic development.

In the absence of an acceptable explanation, Getachew claims there is something else happening, something secret, "seepage." The fact that no one can see where the water is going makes it all the more mysterious. It is a problem without a clear explanation, a secret that the government cannot be expected to reveal.

The actual technology involved in hydropower is important here, as it is both visible and hidden. One sees the structure of the dam and the large body of water that was not previously present, but all else remains hidden. If the water is seeping into the soil, how would anyone know? The process of generating power is also murky. How can the generation of electricity be observed, and who knows where it travels? The state's plan to sell electricity to neighboring nations was well known, and many suspected that this was the cause of the power shortages. They believed Ethiopia lacked power because it was being sold to Sudan and Kenya, and the government was keeping the profits. Although there is no evidence that such sales had begun, rumors such as this were rampant and impossible to disprove.

Getachew and others whom I spoke with shared narratives filled with confusion and suspicion. There was little faith in the explanations advanced through state-run media linking the power shortages to broader development projects. Doubts about the intent of the central government are nothing new in urban Ethiopia, but people have generally assumed that the state will provide such basic services as education, electricity, and water.

The sense of insecurity expressed in Getachew's comments on "seepage" fits with anthropologists' critiques of the neoliberal state in Africa (Ellison 2009; Ferguson 2006; Larkin 2008; Smith 2008). As James Ferguson argues, the core feature of African states' sovereignty "is the ability to provide contractual legal authority that can legitimate the extractive work of transnational firms" (2006:207). In day-to-day discussions, Jimma residents also noted the relationship between a loss of public services and international corporations. Discussions focused less on the economic interests of private corporations than on their inability to work effectively in Ethiopia. For example, in multiple conversations friends noted that Salini had no experience working in Ethiopia's unique geological environment, and this may account for the failure of the Gibe River Dam to generate expected levels 
of hydropower. These conversations express a firm belief in the end of state-led progress and that any project the state undertakes is corrupted by the involvement of international companies interested in extracting profits.

\section{FORCED RELOCATIONS, URBAN PLANNING, AND FAITH IN PROGRESS}

Given the documented failure of African states to effectively provide services to their citizens, it is not particularly surprising that urban Ethiopians express such skepticism about current hydroelectric projects. Based on this, I was surprised by the degree of enthusiasm and support I encountered concerning the construction of roads. There are two asphalt roads that cut through Jimma's densely populated city center. Just off one of these roads is a one-room house where a young woman named Frehiwot lived with her parents. In 2004, when I first met Frehiwot, anyone walking by could see into her family's house, and generally all were welcome in this neighborhood, where everyone knows everyone. Frehiwot's mother moved to Jimma from the surrounding countryside in the early 1970s, and she sold locally distilled liquor out of her home to make a living. Frehiwot's father used to be a butcher, but he no longer works.

In 2008, Frehiwot told me that her family would be forced to move. A large building for coffee sellers would be constructed where her home was, and the state would give her family a house in a neighborhood on the edge of town. The new neighborhood is in a low-lying area, known to be full of mosquitoes. The friends and neighbors who had always been inseparable from Frehiwot's life would no longer be present. There were few potential customers in the new neighborhood, and it was not clear how her mother could make a living.

When I walked by Frehiwot's house in 2009, it was shut off from the street with a corrugated metal fence. Construction had not begun on the new building. I asked some of the local youth what happened to Frehiwot. They said her family moved to the new house, and she was gone. Her brother sent her to Dubai to work as a domestic servant.

The destruction of Frehiwot's house is part of a larger process of state-led urban renewal in Jimma, something people referred to as the five-year plan or the master plan. The most visible element of the plan is the construction of roads. Roads throughout the city were scraped away to be replaced with fresh asphalt. The road near Frehiwot's house was like this. Dirt had been pushed into large piles at the end of each block, making the roads very difficult to navigate and creating 
Frehiwot's was not the only family forced to make way for commercial development, and it is easy to imagine suspicion and controversy concerning road construction, similar to what I encountered concerning hydropower projects. In this case, however, I heard few critiques of state-led development. Instead there was a general sense of enthusiasm about the construction of roads and Jimma's renewal.

Frehiwot's old house was just a few blocks from Ahmed's house. In a different conversation, Getachew expressed a surprising degree of enthusiasm for the government's urban renewal projects. He explained that there is only one way for Third World cities to develop: to push people out of desirable areas.

Unless and otherwise, development will never occur! People simply build houses without having permission from the government. These houses are crowded together and they don't conform to any plan.... The city has a master plan. The master plan designates certain areas for business, living, and recreation. To encourage the city to grow according to the plan, the government will give the residents two options. When the government improves an area by building a new road the residents can improve their homes and businesses to fit with the new standard or sell their property and move somewhere else.

At this point I was getting a little uncomfortable with Getachew's monologue. I interrupted, "Won't people be reluctant to move away from homes where they've lived their entire lives?"

No! People are happy to give up their homes. When a new modern building appears next to their home they won't be comfortable there. They might be forced to move to a neighborhood on the edge of the city where they don't know anyone, but chances are that the new house will be larger than the old one. Most people will welcome this change.

Getachew explained that the government had promised to finish the road as soon as possible. There was a telethon fundraiser scheduled at the Sheraton in Addis Ababa. A filmmaker who was born and raised in Frehiwot's neighborhood would host the event, and people from all over the country would call in and donate money to support development in Jimma. All the teachers had agreed to contribute one month of their salary for the road project. Getachew claimed they had done this because they recognized that the roads are something good and necessary for their community. ${ }^{13}$ 
cuan_1124 can2008.cls December 10, 2011 19:19

CULTURAL ANTHROPOLOGY 27:I

Getachew's enthusiasm for the project may be understood partially in terms of his class position. As a teacher he is a government employee. Although Ethiopian teachers are often highly critical of the ruling party they derive substantial benefits from their position as members of the state. It is unlikely that Getachew or others close to him would be relocated, and he had ties to downtown businesses that would likely see long-term benefits from urban development.

That said, enthusiasm for road construction was not isolated to the middle class. For example, an unemployed young woman told me that she donated five birr and she would have given ten if she could afford it. She announced happily, "It makes me feel wonderful to be able to give even a small amount of money to help my country!”

Such sincere support for a state project is rare in Ethiopia, and yet I encountered people from diverse backgrounds who equated roads with progress. Specific interpretations of progress were not always clear, but it was certainly something worthy of sacrifice. Sometimes people offered more complicated explanations of the importance of roads. Roads promote the movement of goods, and this increases commerce and economic growth. Better roads will most likely decrease the cost of Ethiopian goods, sold both locally and internationally. More commerce should bring more jobs, and with an urban youth unemployment rate of close to 50 percent, Ethiopians are desperately in need of work.

In many ways the road construction in Jimma was similar to the hydroelectric projects. In 2009, few roads had been completed, and for the most part the effects of construction were negative-torn up roads, large amounts of dust, relocation of families, and streets that had become piles of dirt and large muddy puddles. International companies (in this case from China and Korea) carried out most of the work. Yet, although blackouts and hydroelectric projects are interpreted as failures of the state, discussions of roads appear to echo something like classic modernization theory. It was believed that through major investments in infrastructure that Ethiopia will "progress." The tangible results of this progress were vague, but such progress was certainly desirable and worthy of whatever discomfort might be caused.

A key distinction between the hydropower and road construction projects is that the state asked people from all walks of life to support the roads financially. Whether it was giving five birr or a month's salary, a major investment was taking place, both financially and emotionally. The gift of financial support created a relationship among the people, the state, and the proposed infrastructure. Among 
gives and the state gives back in the form of roads. Roads would bring benefits for all. It is important that ideally the financial support for roads was voluntary and not given on a per use basis (this may be contrasted with the metering of water in South Africa described by Von Schnitzler 2008). In this sense the relationship between people and the state was qualitative, rather quantitative. It was based on a mutual willingness to fulfill a need possessed by another.

Significantly, road construction was consistently spoken of as a state project. In contrast to the dams constructed by Salini, the mengist (state or government) was building the roads. The role of international contractors in work being done in Jimma was rarely discussed. The Ethiopian government actively promoted the image of road construction as a state-led project that would bring development to the people. On one occasion I observed a parade of new dump trucks and steamrollers moving through town. Loud music was blaring from the vehicles, and local officials shouted slogans from a megaphone. The trucks were decorated with banners proclaiming in Amharic and Oromo that roads are bringing progress and development to Jimma. Similar parades and events are frequently broadcast on the state-controlled television station that is the only source of televised news for most Ethiopians. Events such as these were a promise of change from the Ethiopian government. Such attempts to replace state led development with "performance and conjury" have been identified elsewhere in Africa (Piot 2010:38). In the case of road construction in Jimma, despite an overwhelming sense of cynicism about state promises, people felt that they were part of the project.

\section{CREATING A RELATIONSHIP WITH THE STATE THROUGH ROCKS AND WORK}

A sense of personal investment in road construction was particularly strong among the many young men who had found work on these projects. Building roads puts people to work. In addition to the many asphalt roads being constructed around Jimma there are also smaller roads in neighborhoods that are built from rocks and resemble cobblestone streets. Only a couple small roads, the equivalent of one or two city blocks, were close to being finished in 2009, but there was a great deal of excitement among young men about these projects. Beginning in the mid-1990s the unemployment rate in Jimma has hovered at around 50 percent among urban youth between the ages of 18 and 30, and lengths of unemployment average three to four years (Serneels 2007). In recent years the streets and corners of Jimma have been crowded with unemployed young men, hanging about, chewing khat, and talking (Mains 2007). There are still a lot of idle young men hanging around, but not as 
cuan_1124 can2008.cls December 10, 2011 19:19

CULTURAL ANTHROPOLOGY 27:1

many as in years past. Instead, many of them are doing "rock work" - breaking the stones and using the smaller pieces to construct roads. The construction of asphalt roads by international companies certainly does create jobs, but it does not compare to the amount of work necessary to build roads by hand.

Holyfield was one of the young men I could always find on a corner near the house I rented when I lived in Jimma between 2003 and 2005. He is very well built, with a broad muscular back, and he takes his nickname from the American boxer whom his friends think he resembles. Although he was unemployed and his family was certainly not wealthy, he always managed to be dressed in fashionable soccer jerseys and jeans, and others occasionally teased him about the efforts he took to keep himself clean. When I returned to Jimma in 2008, Holyfield was not around. After a few years of unemployment he had left Jimma to find work with Salini, on the second phase of the Gibe River hydroelectric project (Gibe II). Eventually the project slowed down and Holyfield returned to Jimma, hoping to find work with a Korean road construction project. When this failed, he began doing rockwork.

When we met again in 2009, Holyfield was wearing a brilliant yellow tracksuit with "Brazil" printed across the front and dark wrap-around shades that take on a rainbow sheen when they reflect the sun. He took great pride in telling me about his involvement in the government-sponsored rockwork and encouraged me to visit the work site. He was paid 1.5 birr for every stone he set. He could easily make at least 45 birr per day (around $\$ 4$ at the time), and he often earned more than this.

After I arrived in Jimma in 2009 the rockwork slowed down. As I made my way through the city, I often passed by large piles of rocks covered by tents for shade, but I rarely saw anyone working. I still did not see Holyfield as much as I did in years past, but I began to run into him hanging out with other young men on the corner. He told me that there was a shortage of materials, but the work would begin again soon. However, days passed and the work did not begin.

Despite the lack of work, Holyfield expressed little cynicism regarding the government's efforts at development. He explained that as the neighborhood changes, businesses are constructed, and wealthier families move in, it is likely that his family may be forced to go elsewhere, but this will not be a bad thing. His family will be given land somewhere else. It may be far from the city center but it will not be any great trouble to commute into the city. I mentioned the mosquitoes and swampy conditions in new neighborhoods, and Holyfield responded that the 
that everyone wins when businesses and wealthy families displace others. He explained that roads are very important; without roads progress is impossible.

It is important that Holyfield speaks of himself as a government employee. It is the state that has given him this work, and the exchange of his labor for income implies a qualitative shift in his relationship to the government. To some extent Holyfield has now become part of the state. Much of the actual funding for the construction of these cobblestone roads comes from a German NGO, but Holyfield and other young men consistently spoke of the roads as a government project. I have described elsewhere the qualitative differences between government employment and work in the urban informal economy in Ethiopia (Mains 2012 b). Government work implies a relationship between individuals who are differently positioned within a hierarchy of power that extends beyond the workplace, but relations of power in the informal economy are generally isolated to the moment of exchange. This distinction is an important factor behind the relatively high status of government employment and low status of work in the informal economy.

For rock workers like Holyfield and teachers like Getachew, road construction creates desirable relations of exchange with the state. These are not the personal patron-client relations that individuals often seek to cultivate with state representatives. Here the relationship is with a much more abstract and impersonal state. In exchange for one's allegiance the state provides infrastructure or, more important for Holyfield, paid work. It is not simply that the state is offering a desirable good that is significant. Like many young men, Holyfield had worked for a private company, but in discussing this work there was no assumption that the relationship with the company shifted his identity. State employment signifies the presence of a qualitative relationship between the worker and an abstractly conceived "government." This relationship is assumed to extend far beyond the workplace to encompass more personal social interactions. The young male rock worker is becoming part of the state, and many young men are willing to put aside their cynicism about the ruling party in exchange for such a relationship. In Getachew's case, at the same time as he critiques the state he expresses a desire to maintain a relationship with it. The abstract relationship with the state is concretized through Getachew's day-to-day interactions with others that are structured by his role as a government employee. It is the perceived potential of road construction for (re)creating this relationship with the state that has led Jimma residents to invest emotionally in an infrastructural development project that at first glance differs little from the apparent failure of the local hydropower dam. 
cuan_1124 can2008.cls December 10, 2011 19:19

CULTURAL ANTHROPOLOGY 27:I

For Getachew and young men like Holyfield, the sense of membership associated with state employment is linked to class. Getachew's support for road construction and urban renewal is indicative of his desire to maintain his position within a middle class. Holyfield's position, however, is based in aspiration. Unemployed young men consistently voiced a desire to attain government employment. Such employment not only brings a steady income but also immediately inserts one into a complex and qualitatively desirable web of relationships. In the absence of traditional government jobs, rockwork offers an acceptable alternative. The rock worker is paid by the piece, rather than a monthly salary, benefits are nonexistent, and there is no evidence that the work will extend beyond the duration of the current project. For underemployed young men, however, there is still hope to be found in this work. For the moment it is possible for them to assert a relationship with the state that despite its dubious economic value has historically been associated with the urban middle class in Ethiopia.

\section{CONCLUSIONS: THE PROBLEMS OF NEOLIBERALISM(S) AS AN} ANALYTICAL CATEGORY

Participating in the construction of roads - through donating money, selling one's labor, or simply providing moral support - creates a sense that one is with the state. Given the generally high level of cynicism regarding the state, such a desire for a relationship is surprising, and its prevalence is an indication of the historical importance in urban Ethiopia of maintaining a personal relationship with the state, as a source of both status and economic mobility. To be a government worker provides a sense of membership within a desirable community. One is part of a wide network of state employees that is associated with social activities that extend far beyond the workplace and include weddings, funerals, and religious feasts. At the same time, despite recent changes, the state has historically been the primary source of economic opportunity within urban Ethiopia. Government work provides security as well as opportunities for further advancement both professionally and otherwise (e.g., access to low-cost government housing). Road construction reasserts a relationship with the state. The state is perceived as reemerging as a provider and the basis for community.

I have demonstrated that the privatization of infrastructural development in Ethiopia does not fit easily with conceptions of neoliberalism. At the same time, to argue that the Ethiopian case represents a particularly localized version of neoliberalism has limited analytical utility. My intent is not to dismiss recent 
rich and theoretically nuanced analyses of issues such as the creation of subjectivities, restructuring of the state, and the rationalization of economies. I do, however, believe that at this point the continued value of using neoliberalism as a category of analysis is diminishing, and anthropologists would be well served by moving toward analyses of correlations and patterns among specific practices. The problem of using neoliberalisms is that although they avoid a singular and unified neoliberalism, they are still based in the assumption that certain policies, practices, and values may be categorized usefully as neoliberal. Given the broad range of things that neoliberal refers to, its utility as a category is limited.

Ferguson offers a clear description of the multiple ways that neoliberalism is used, considers the possibility of abandoning the term altogether, and then concludes that a word that bring together multiple meanings "can be an occasion for reflecting on how the rather different things to which it refers may be related" (2010:172). Ferguson certainly does make a compelling case for using this "confusing, conflating word” (2010:172) in his analysis of Basic Income Grants in South Africa. What makes Ferguson's analysis so valuable, however, is not his use of neoliberalism but the manner in which he breaks the term down into distinct mechanisms of governance at play in South Africa. Ferguson analytically decouples the political agenda generally associated with neoliberalism from specific techniques of governance that are often categorized as neoliberal. In other words, neoliberalism as a class project does not necessarily correlate with individualizing techniques of governance. A much more straightforward means of making his argument would be simply to avoid the use of neoliberalism and to examine correlations between specific practices. By disassociating particular political techniques, subjectivities, and desires from the overly broad category of neoliberalism, opportunities are created for a fresh perspective and new insights. ${ }^{14}$ My critique of Ferguson's essay may be applied to many recent discussions of neoliberalisms. Invoking neoliberalisms only confuses and muddles important insights regarding relationships between specific issues such as privatization, affective relationships, and resource distribution.

Building on Collier's (2009) discussion of "topologies of power" I believe it is necessary to move beyond using neoliberalism as a primary category of analysis and instead examine correlations between different practices. As Collier explains: "We can trace certain techniques and technical mechanisms from one context to the other. . . But there is no reason to assume that the resulting governmental ensembles can be read as playing out some internal logic of neoliberalism" (2009:100). In this article, I have described how economic and political processes common to much 
of the developing world have been applied in the Ethiopian case. Hydropower and road construction projects demonstrate that Jimma residents perceive the Ethiopian state as simultaneously contracting and expanding. Individuals and communities engage with infrastructural development and cultural and historical norms surrounding power and exchange to reposition themselves in relation to the state. To frame this analysis in terms of neoliberalism would obscure more than it reveals. By breaking my analysis down into correlations between specific policy changes and types of power relations I hope that I have generated insights into how power may function in similar cases and provided the grounds for developing the sort of midlevel theories that anthropological research often supports (Knauft 2006).

\begin{abstract}
The recent completion of a hydropower dam near Jimma, Ethiopia coincided with rolling blackouts throughout the country and accusations of corruption and mismanagement being directed toward the Ethiopian government and the Italian company that constructed the dam. The case appears to be one more example of an African state failing to provide its citizens with basic public services in a context of neoliberal economic restructuring. Recent road construction and urban renewal projects in Jimma have also been contracted out to private companies and have led to displaced families and disruptions of day-to-day life. Jimma residents, however, have generally met these projects with statements of approval and appreciation for the power of the Ethiopian state to bring progress. In this article, I examine contrasting narratives concerning privatized infrastructural development projects. I argue that although the provision of basic services is increasingly contracted out to private companies, the perceived presence of the Ethiopian state has expanded in new and surprising ways. Contrasting perceptions of dams and road construction are based in values concerning relations of power and exchange. In this case, the particular relationship between the privatization of infrastructure and perceptions of the state demonstrates the limits of neoliberalism as an analytical category. I argue that in recent anthropological scholarship a reliance on neoliberalism as a category of analysis obscures more than it reveals, and I call for more attention to correlations between specific techniques of governance and relations of power. [development, infrastructure, neoliberalism, patron-client relations, progress]
\end{abstract}

\title{
NOTES
}

Acknowledgments. This article is based on research supported by National Science Foundation Grant \#0717608 and a Fulbright-Hays Fellowship. I am grateful to Chandra Bhimull, Mary Beth Mills, Maple Razsa, Jed Stevenson, and Winifred Tate for comments on earlier drafts of this article. Thanks to Anne Allison, Charles Piot, and three anonymous reviewers for comments that were extremely helpful in revising this article. 
1. One of these projects, Gibe II, an underground tunnel designed for generating hydropower, was finished in 2010 but then suffered a collapse shortly after its inauguration. This led to further cutbacks in the availability of power throughout Ethiopia. In early 2011, Gibe II was repaired and started to generate power.

2. The Gibe River projects have received a great deal of international scrutiny. Salini received no-bid contracts for the second and third stages of the Gibe River projects, violating Ethiopia's policies for international bidding. Proper geological surveys were not conducted prior to beginning construction on the projects, and claims of power generation are likely exaggerated. It is likely that most of the power generated will be used by private industry, as power lines do not exist to transmit electricity to Ethiopia's predominantly rural population. The third stage of the Gibe project will have major impacts on the Omo River Valley and devastating effects on the lives of more than 500,000 people who depend on the river for fishing, farming, and water for livestock. Because of growing critiques of Gibe III, which would be the world's tallest dam, many international lenders, including the World Bank, backed away from the project. The Industrial and Commercial Bank of China announced in 2010 that it will support the project with a $\$ 500$ million loan, with the stipulation that a Chinese state-owned company will provide equipment for the project (Hathaway 2008; International Rivers 2009; CEE Bankwatch Network 2008).

3. Nearly 80 percent of housing units in Jimma had at least one electric light in 1994. Numbers are higher for larger cities like Addis Ababa and Dire Dawa, where around 95 percent of housing units had electric lights, and these numbers represent a slight increase from 1984 (Abelti et al. 2001). At the time of the 1994 census, less than 15 percent of Ethiopia's population lived in urban areas, and there continues to be very little access to electricity in rural areas.

4. By "privatization of infrastructural development" I refer to the use of public money to hire private contractors to construct infrastructure, like hydroelectric dams, mobile phone towers, and roads.

5. John Clarke explores the utility of neoliberalism as an analytical category and concludes that we need "terms that would allow us to think better" (2008:145). I agree with Clarke's critique of neoliberalism as an overly promiscuous, omnipresent, and omnipotent concept and I suggest that this problem can be solved by focusing on specific correlations between sets of practices.

6. Derg is the Amharic word for "committee."

7. In Amharic, the language most commonly used in Jimma and much of urban Ethiopia, both "state" and "government" are referred to with the word mengist, and little distinction is made between the two. Local government administrators are generally associated with the authority of the state and the ruling party (Vaughan and Tronvoll 2003).

8. Extremely high attendance at the funeral of any government worker was one indication of his or her high status. See Mains 2012b for an extended discussion of status and government employment.

9. For a more detailed discussion of youth and relations of power in the context of the 2005 elections see Mains 2012a.

10. By 2008, mobile phones had begun to spread to urban working-class men. Texting was common primarily among those with at least a secondary education. Although many urban residents would not directly send and receive a message like this, it was common for mobile phone owners to read such humorous messages together with their friends.

11. See Ulimwengu et al. 2009 for a quantitative analysis of rising food prices in Ethiopia.

12. I use pseudonyms for all individuals discussed in this article.

13. In 2011, representatives of the Ethiopian federal government visited the United States to meet with Ethiopian Americans in different major cities in hopes of soliciting donations in support of infrastructural development. In many cases large protests were held outside of the meetings. Popular Ethiopian musicians like Fiker Addis have released songs promoting infrastructural development. Videos accompanying the songs, posted on YouTube, include images of rivers, dams, and Ethiopians signing off on government issued bonds. 
14. One might argue that the techniques of governance described by Ferguson are usefully categorized as "neoliberal." Although developing categories to group particular sets of techniques is certainly useful, the numerous ways that neoliberal has been used undermine its utility in such an analysis. Because neoliberal is embedded in so many different language games, it is not possible to simply use it to speak about something as specific as a set of techniques of governance.

\section{REFERENCES CITED}

Abelti, Gebeyehu, Marco Brazzoduro, and Behailu Gebremedhin

2001 Housing Conditions and Demand for Housing in Urban Ethiopia. Addis

Caldeira, Teresa Ababa: Central Statistical Authority.

2001 City of Walls: Crime, Segregation, and Citizenship in Sao Paulo. Berkeley: University of California Press.

CEE Bankwatch Network

2008 The Gilgel Gibe Affair: An Analysis of the Gilgel Gibe Hydroelectric Projects in Ethiopia. Research Paper. Prague: CEE Bankwatch Network.

Clarke, John

2008 Living with/in and without Neoliberalism. Focaal-European Journal of Anthropology 51:135-147.

Collier, Stephen

2009 Topologies of Power: Foucault's Analysis of Political Government beyond "Governmentality." Theory, Culture and Society 26(6):78-108.

Donham, Donald

1999 Marxist Modern: An Ethnographic History of the Ethiopian Revolution. Berkeley: University of California Press.

Economist

2011 Africa's Impressive Growth. http://www.economist.com/blogs/dailychart/

Ellison, James 2011/01/daily_chart?page $=2$, accessed May 3, 2011.

2009 Governmentality and the Family: Neoliberal Choices and Emergent Kin Relations in Southern Ethiopia. American Anthropologist 111(1):81-92.

Ferguson, James

1999 Expectations of Modernity: Myths and Meanings of Urban Life on the Zambian Copperbelt. Berkeley: University of California Press.

2006 Global Shadows: Africa in the Neoliberal World Order. Durham, NC: Duke University Press.

2007 Formalities of Poverty: Thinking about Social Assistance in Neoliberal South Africa. African Studies Review 50(2):71-86.

2010 The Uses of Neoliberalism. Antipode 41(supp. 1):166-184.

Gemeda, Guluma

1987 An Outline of the Early History of Jimma Town. Paper Presented at the Fourth Annual Seminar of the Department of History, Addis Ababa University, Ghosh, Kaushik Awassa, Ethiopia, July 9-11.

2006 Between Global Flows and Local Dams: Indigenousness, Locality, and the Transnational Sphere in Jharkhand, India. Cultural Anthropology 21(4):501534.

Harvey, David

2005 A Brief History of Neoliberalism. Oxford: Oxford University Press.

Hassen, Mohammed

1990 The Oromo of Ethiopia: A History 1570:1860. Cambridge: Cambridge 
Hathaway, Terry

2008 What Cost Ethiopia's Dam Boom?: A Look Inside the Expansion of Ethiopia's

Hoben, Allan Energy Sector. Berkeley: International Rivers.

1970 Social Stratification in Traditional Amhara Society. In Social Stratification in Africa. Arthur Tuden and Leonard Plotnicov, eds. Pp. 187-224. New York: Free Press.

1973 Land Tenure among the Amhara of Ethiopia. Chicago: University of Chicago Press.

Holston, James

2009 Insurgent Citizenship: Disjunctions of Democracy and Modernity in Brazil. Princeton: Princeton University Press.

International Rivers

2009 Ethiopia's Gibe 3 Dam: Sowing Hunger and Conflict. Berkeley: International Rivers.

James, Wendy, Donald Donham, E. Kurimoto, and A. Triulzi, eds.

2002 Remapping Ethiopia: Socialism and After. Oxford: James Currey.

Kanna, Ahmed

2010 Flexible Citizenship in Dubai: Neoliberal Subjectivity in the Emerging "City-Corporation" Cultural Anthropology 25(1):100-129.

Kingfisher, Catherine, and Jeff Maskovsky

2008 Introduction: The Limits of Neoliberalism. Critique of Anthropology 28(2):115-126.

Kipnis, Andrew

2008 Audit Cultures: Neoliberal Governmentality, Socialist Legacy, or Technologies of Governing? American Ethnologist 35(2):275-289.

Knauft, Bruce

2006 Anthropology in the Middle. Anthropological Theory 6(4):407-430.

Krishnan, Pramila, Tesfaye Gebre Sellasie, and Stefan Dercon

1998 The Urban Labor Market During Structural Adjustment: Ethiopia 1990 - 1997.

Working Paper, 98-9. Oxford: Center for the Study of African Economies.

Larkin, Brian

2008 Signal and Noise: Media, Infrastructure, and Urban Culture in Nigeria.

Durham, NC: Duke University Press.

Lewis, Herbert

2001 Jimma Abba Jifar: An Oromo Monarchy, Ethiopia 1830-1932. Lawrenceville, NJ: Red Sea Press.

Mains, Daniel

2007 Neoliberal Times: Progress, Boredom, and Shame among Young Men in Urban Ethiopia. American Ethnologist 34(4):659-673.

2012a Cynicism and Hope: Urban Youth and Relations of Power During the 2005 Ethiopian Elections. In Contested Power in Ethiopia: Traditional Authorities and Multi-Party Elections. Kjetil Tronvoll and Tobias Hagmann, eds. Pp. 137-163. Leiden, the Netherlands: Brill Academic.

2012b Hope is Cut: Youth, Unemployment and the Future in Urban Ethiopia. Philadelphia: Temple University Press.

McMichael, Philip

1996 Development and Social Change: A Global Perspective. Thousand Oaks, CA: Pine Forge.

Moore, Donald

1999 The Crucible of Cultural Politics: Reworking "Development" in Zimbabwe's Eastern Highlands. American Ethnologist 26(3):654 689.

Ong, Aihwa

2006 Neoliberalism as Exception: Mutations in Citizenship and Sovereignty. Durham, NC: Duke University Press. 
Pankhurst, Alula

1992 Resettlement and Famine in Ethiopia: The Villagers' Experience. Manchester: Manchester University Press.

Pankhurst, Alula, and Francois Piguet

2009 Moving People in Ethiopia: Development, Displacement and the State. Oxford: James Currey.

Piot, Charles

2010 Nostalgia for the Future: West Africa after the Cold War. Chicago: University of Chicago Press.

Poluha, Eva

2004 The Power of Continuity: Ethiopia through the Eyes of its Children. Uppsala: Nordiska Afrikainstitutet.

Richland, Justin

2009 On Neoliberalism and Other Social Diseases: The 2008 Sociocultural Anthropology Year in Review. American Anthropologist 111(2):170-176.

Rist, Gilbert

2002 The History of Development: From Western Origins to Global Faith. London: Zed.

Rudnyckyj, Daromir

2009 Spiritual Economies: Islam and Neoliberalism in Contemporary Indonesia.

Schwegler, Tara Cultural Anthropology 24(1):104-141.

2008 Take It From the Top (Down)? Rethinking Neoliberalism and Political Hierarchy in Mexico. American Ethnologist 35(4):682-700.

Scott, James

1998 Seeing Like a State: How Certain Schemes to Improve the Human Condition Have Failed. New Haven, CT: Yale University Press.

Serneels, Pieter

2007 The Nature of Unemployment among Young Men in Urban Ethiopia. Review of Development Economics 11(1):170-186.

Shever, Elana

2008 Neoliberal Associations: Property, Company, and Family in the Argentine

Smith, Daniel Oil Fields. American Ethnologist 35(4):701-716.

2008 A Culture of Corruption: Everyday Deception and Popular Discontent in Nigeria. Princeton: Princeton University Press.

Ulimwengu, John, Sindu Workneh, and Zelekawork Paulos

2009 Impact of Soaring Food Price in Ethiopia: Does Location Matter? Washington, DC: International Food Policy Research Institute.

Vaughan, Sarah, and Kjetil Tronvoll

2003 The Culture of Power in Contemporary Ethiopian Political Life. Stockholm: SIDA.

Verdery, Katherine

1996 What Was Socialism and What Comes Next? Princeton: Princeton University Press.

Von Schnitzler, Antina

2008 Citizenship Prepaid: Water, Calculability, and Technopolitics in South Africa. Journal of Southern African Studies 34(4):899-917.

Editors' Notes: Cultural Anthropology has published a number of essays on state and development, including Karen Strassler's "The Face of Money: Currency, Crisis, and Remediation in Post-Suharto Indonesia” (2009), Paul W. Hanson's 
cuan_1124 can2008.cls December 10, $2011 \quad 19: 19$

"Governmentality, Language Ideology, and the Production of Needs in Malagasy Conservation and Development” (2007), and Blair Rutherford's "Desired Publics, Domestic Government, and Entangled Fears: On the Anthropology of Civil Society, Farm Workers, and White Farmers in Zimbabwe” (2004).

Cultural Anthropology has also published a number of essays on citizenship. See, for example, Jessica Cattelino's “The Double Bind of American Indian Need-Based Sovereignty" (2010), Ahmed Kanna's "Flexible Citizenship in Dubai: Neoliberal Subjectivity in the Emerging "City Corporation" (2010), Francis Cody's "Inscribing Subjects to Citizenship: Petitions, Literacy Activism, and the Performativity of Signature in Rural Tamil India” (2009), and Ritty Lukose's "Empty Citizenship: Protesting Politics in the Era of Globalization” (2005). 